\title{
CONF- $960615-1$ \\ THE ROLE OF ENERGY EFFICIENCY AND RENEWABLE ENERGIES IN THE FUTURE WORLD ENERGY MARKET
}

\author{
JOHN SHEFFIELD
}

\author{
OAK RIDGE NATIONAL LABORATORY \\ P. O. BOX 2008 \\ OAK RIDGE, TENNESSEE 37831-6248
}

\begin{abstract}
The world population is rising rapidly, notably in the developing countries. Historical trends suggest that increased annual energy use per capita is a good surrogate for the standard of living factors which promote a decrease in population growth rate. If these trends continue, the stabilization of the world's population will require the increased use of all sources of energy as cheap oil and gas are depleted. The improved efficiency of energy use and renewable energy sources will be essential to stabilizing population, while providing a decent standard all over the world.
\end{abstract}

\section{KEYWORDS}

Population, Energy Demand, Energy Efficiency, Renewable Energies

\section{INTRODUCTION}

Today, renewable energy is some $13 \%$ of the world annual energy use of about 9,000 million tonnes of oil equivalent (Mtoe/a; 1 toe $=42 \mathrm{GJ}$ ). Fossil fuels account for the bulk, about $80 \%$, of the energy use. In the future, it is postulated that these roles will change as energy demand rises and cheap oil and gas are depleted; even without consideration of global warming effects. The changes will be driven mainly by the developing areas, which have relatively less of the fossil fuel reserves, but have a substantial potential to deploy renewable energies.

A study of historical trends suggests that population growth rate may be viewed as depending, roughly, on a mixture of two factors relating to culture and standard of living respectively (Goldemberg, Johansson, 1995; Duchin, 1995). A good surrogate for standard of living appears to be the annual energy use per capita (Goldemberg, Johansson, 1995). The author has developed a simple relationship, which permits coupled annual values of population growth rate and energy use per capita to be derived for each part of the developing world - Africa, China, East Asia, South Asia, and Latin America. The growth rate is updated every decade. 


\section{DISCLAIMER}

Portions of this document may be illegible in electronic image products. Images are produced from the best available original document. 
Annual Growth rate $=\left(E_{\mathrm{C}}-E_{a}\right) /\left(160 E_{a} 0.38\right)$;

- where $E_{a}$ is the annual energy use per capita, adjusted for efficiency gains obtained after the year 2000 (i.e., a 50\% efficiency improvement allows a given amount of primary energy to be worth 1.5 times as much in supporting the standard of living);

- and $E_{C}$ is the annual effective energy use per capita at which the population growth rate is zero (typically 2 to 3 toe/cap.a today). It may be viewed as a measure of the cultural factors.

\section{REFERENCE CASE}

The reference case for projecting world population and energy use assumes that steady efficiency gains will be made across-the-board from 2000 , rising to $37.5 \%$ by $2050,75 \%$ by 2100 , and $100 \%$ by 2200 .

The World Bank population projections (Bos, et al, 1994) and the energy/capita predicted by the International Energy Agency (IEA) (World Energy Outlook, 1995) for 2010 are used for the OECD countries of Europe, the East, and North America, and the Former Soviet Union, Centrally Planned Europe, and the Middle East. These countries have low population growth rate or in the latter case unclear connection of population to energy use. The energy per capita is decreased in proportion to the efficiency improvements. The alternative case in which these areas take efficiency improvements as an increase in standard of living is also calculated.

For the developing areas, the primary annual energy per capita is increased systematically beyond the level predicted for 2010 by the IEA so as to stabilize each population in the time period 2100 to 2150. The starting factor $E_{c}$ is chosen to match the present day trends and is allowed to decrease with time (See Fig. 1 for the example of South Asia for which $E_{c}=2.5$ initially and decreases to 2.0 by 2100 ).

Historical values are used for 1971-1992; predictions of the IEA (World Energy Outlook, 1995) and the World Bank (Bos, et al, 1994) for 1992-2010; and the reference case of this paper for 2010 to 2100 . Interestingly, this approach led to population evolution for developing areas similar to those of the World Bank's standard case (Bos, et al, 1995).

Reference case of this paper:

$\begin{array}{lc}\text { Area } & \mathrm{E}_{\mathrm{C}}(10)-\mathrm{E}_{\mathrm{c}}(100) \\ \text { Africa } & 2.6--2.2 \\ \text { China } & 2.5--2.0 \\ \text { East Asia } & 3.0--2.4 \\ \text { South Asia } & 2.5--2.0 \\ \text { Latin Amer. } & 3.5--2.8 \\ \text { World } & \end{array}$

Stable Population
3,140 millions
1,700 millions
1,140 millions
2,850 millions
940 millions
11,810 millions
Peak Energy Demand
3,270 Mtoe/a
$2,250 \mathrm{Mtoe} / \mathrm{a}$
$1,530 \mathrm{Mtoe} / \mathrm{a}$
3,000 Mtoe/a
$1,410 \mathrm{Mtoe} / \mathrm{a}$
15,900 Mtoe/a

\section{VALUE OF EFFICIENCY GAINS}

For the reference case, the world peak annual energy use is 15,900 Mtoe/a:

a.) If the efficiency improved more slowly, e.g., to $25 \%$ by $2050,50 \%$ by 2100 and $95 \%$ by 2200 , the peak energy would be 18,100 Mtoe/a. The integrated increase in energy demand from 2010 to 2100 would be 138,000 Mtoe. This is comparable with the total proven plus projected recoverable natural gas reserves (World Energy Council, 1995).

b.) If the developed world, FSU, CEE, and Middle East chose to take efficiency gains to increase their standard of living, rather than to reduce energy use, the energy increment 2010-2100 would be 110,000 Mtoe. 
Total proven and projected, recoverable, oil reserves are 212,000 Mtoe. (World Energy Council, 1995).

\section{RENEWABLE ENERGY DEMAND}

A substantial potential is believed to exist in the world for renewables; for biomass (Johansson, et al, 1993), 4,900 Mtoe/a; for hydropower (World Energy Council, 1995), 780 Mtoe/a (electric); and for windpower (Sorensen, 1995), $4540 \mathrm{Mtoe} / \mathrm{a}$ (electric). Roughly half of these energy resources are in developing countries. The rest of the energy will have to be supplied by fossil, solar, geothermal and nuclear (fission and fusion) sources. While China and Latin America have large fossil energy resources compared to their expected demands, Africa, East Asia, and South Asia do not. In addition, fossil fuels are not evenly distributed in Africa, Asia, and Latin America. In South Asia it is projected for the reference case that demand will rise to 2,900 Mtoe/a, while proven and projected, recoverable, fossil resources are $\approx 80,000$ Mtoe. Similarly, for Africa the projection is for up to 3,200 Mtoe/a, while fossil reserves are $\geq 100,000 \mathrm{Mtoe}$. It can be expected that these areas will favor their indigenous sources, which are primarily renewable energies. An example distribution of world energy sources for the reference case is shown in Fig. 2. For each area preference was given to indigenous energy sources; on the average, $55 \%$ of the potential biomass, $95 \%$ of the hydropower and $20 \%$ of the wind power was deployed, with the highest percentages in the areas which had the greatest need. The balance of solar and nuclear (fission + fusion) energy use will depend upon the relative costs, technical capabilities of each area and public acceptance. The alternative to their use is probably a greater use of fossil fuels. For the reference case, renewable energies rise to over $60 \%$ of the total energy use. The consequences of not having the energy available, within this model, would be massive population increases in the deprived areas and, ultimately, the same demand for energy but from more poverty stricken populations! It is essential, therefore, that energy efficiency improvements and all energy sources, importantly renewables, are developed and deployed rapidly to ensure that the converse occurs population stabilization with a decent standard of living for all!

\section{REFERENCES}

Bos, E., My T. Vu, E. Massiah, and R. A. Bulatao (1994). World Population Projections: 1994-95 Edition, published for the World Bank by The Johns Hopkins University Press, Baltimore and London.

Duchin, F. (1995). Global Scenarios about Lifestyle and Technology, The Sustainable Future of the Global System, United Nations University, Tokyo.

Goldemberg, J. and T. B. Johansson (1995). Energy as an Instrument for Socio-Economic Development. United Nations Development Programme. New York, New York. pp 9.

Johansson, T. B., H. Kelly, A. K. N. Reddy, and R. H.Williams (1993) Renewable Fuels and Electricity for a Growing World Economy: Defining and Achieving the Potential. In: Renewable Energy: Sources for Fuels and Electricity (T. B. Johansson, et al.). Washington: Island Press.

Sorensen, B. (1995). History of, and Recent Progress in, Wind-Energy Development. Annual Review of Energy and the Environment, Vol. 20, p487. Annual Reviews, Inc., Palo Alto, CA, USA.

World Energy Council (1995). 1995 Survey of Energy Resources. Holywell Press Ltd, Oxford, England.

World Energy Outlook (1995). International Energy Agency. OECD Publications. 2 rue Andre Pascal, Paris, France. 


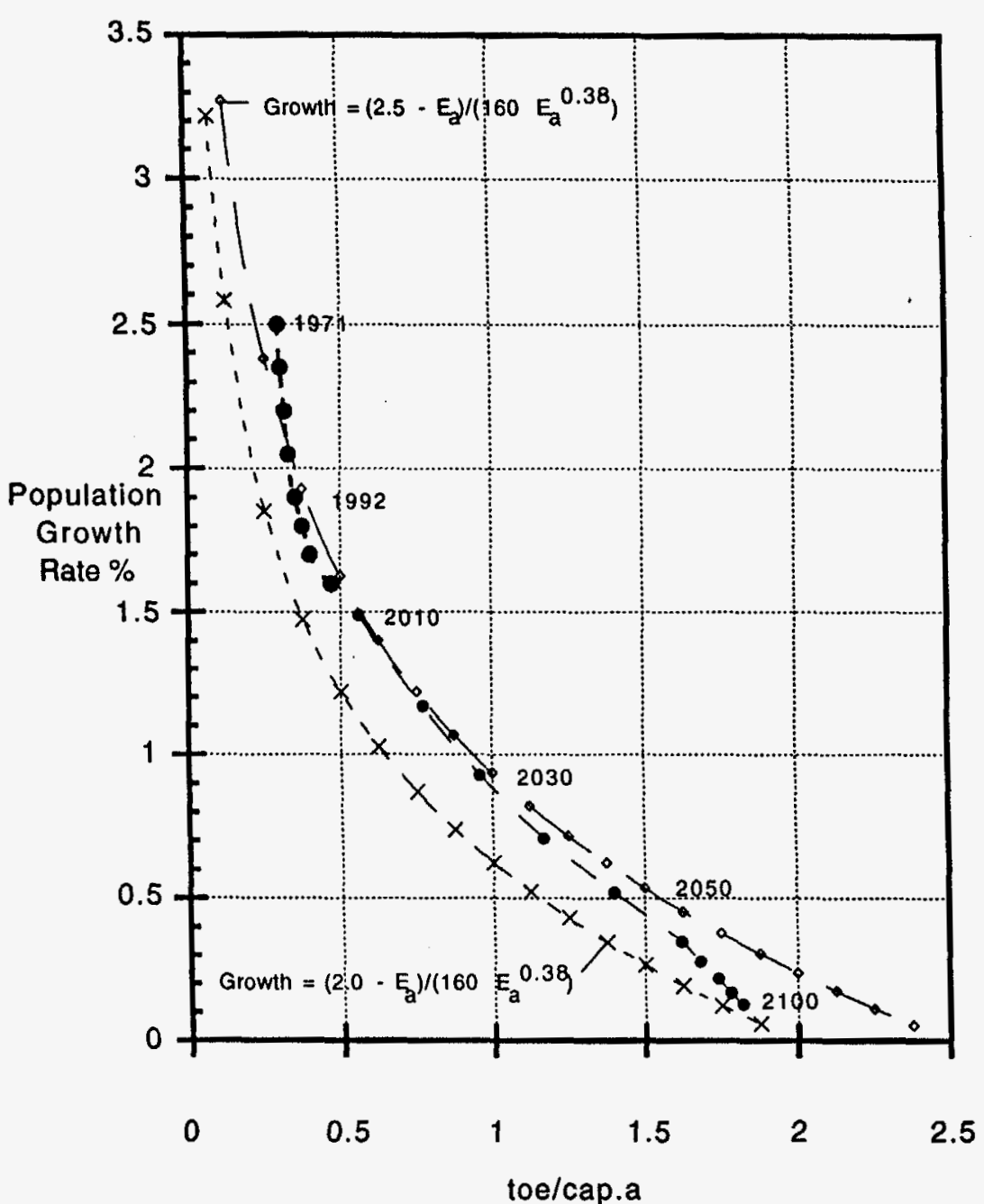

Fig. 1. South Asia population growth rate versus annual energy use per capita: 1971-1992 historical data [1,2]; 1992-2010 predictions [1,2]; 2010-2100 reference case projections: adjusted energy.

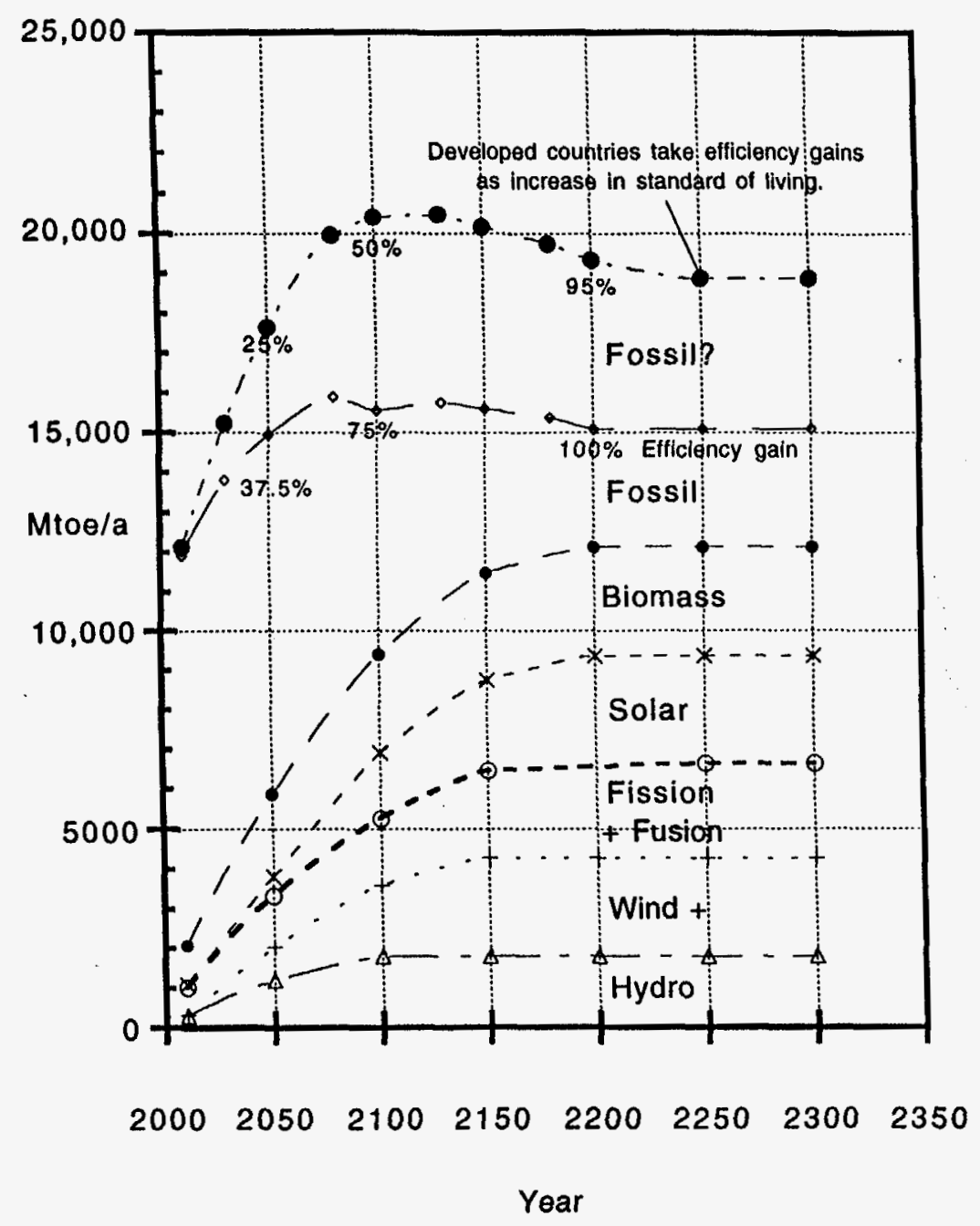

Fig. 2. Total Annual Energy Use for 2010 to 2300 with Potential Energy Sources (added to give total): a.) Lower Efficiency and developed countries take efficiency gains as increase in standard of living. b) Higher efficiency gains and developed countries use gains to reduce energy use. 


\section{Disclaimer}

This report was prepared as an account of work sponsored by an agency of the United States Government. Neither the United States Government nor any agency thereof, nor any of their employees, makes any warranty, express or implied, or assumes any legal liability or responsibility for the accuracy, completeness, or usefulness of any information, apparatus, product, or process disclosed, or represents that its use would not infringe privately owned rights. Reference herein to any specific commercial product, process, or service by trade name, trademark, manufacturer, or otherwise does not necessarily constitute or imply its endorsement, recommendation, or favoring by the United States Government or any agency thereof. The views and opinions of authors expressed herein do not necessarily state or reflect those of the United States Government or any agency thereof.

This report has been reproduced directly from the best available copy.

Available to DOE and DOE contractors from the Office of Scientific and Technical Information, 175 Oak Ridge Turnpike, Oak Ridge, TN 37831; prices available at (615) 576-8401.

Available to the public from the National Technical Information Service, U.S. Department of Commerce, 5285 Port Royal Road, Springfield, VA 22161; phone orders accepted at (703) 487-4650. 